\title{
АНАЛІЗ ЧИННИКІВ РОЗВИТКУ НАУКОВОГО ПОТЕНЦІАЛУ В ТЕРНОПІЛЬСЬКОМУ ДЕРЖАВНОМУ МЕДИЧНОМУ УНІВЕРСИТЕТІ ІМЕНІ І. Я. ГОРБАЧЕВСЬКОГО
}

\author{
Л. С. Бабінець, О. М. Сопель, К. О. Пашко \\ ДВНЗ “Тернопільський держсавний медичний університет імені І. Я. Горбачевського МОЗ Украӥни”
}

\section{ANALYSIS OF FACTORS IN THE DEVELOPMENT OF SCIENTIFIC POTENTIAL IN THE TERNOPIL STATE MEDICAL UNIVERSITY BY I. YA. HORBACHEVSKY}

\author{
L. S. Babinets, O. M. Sopel, K. O. Pashko \\ SHEI "Ternopil State Medical University by I. Ya. Horbachevsky of MPH of Ukraine"
}

\begin{abstract}
У статті коротко проаналізовані заходи сприяння розвитку наукового потенціалу у 2007-2011 роки у Тернопільському державному медичному університеті імені І. Я. Горбачевського.
\end{abstract}

The article briefly analyzes the measures to promote scientific capacity in 2007-2011 years in the Ternopil State Medical University by I. Ya. Horbachevsky.

Вступ. Стандарти і рекомендації щодо забезпечення якості освіти в Свропейському освітньому просторі вищої освіти вимагають від вищих навчальних закладів забезпечити розробку і втілення у життя стратегії постійного підвищення якості навчального процесу. Пункт 1.4 частини 1 прямо вимагає: "Навчальні заклади повинні мати у своєму розпорядженні певні процедури і критерії, які б засвідчували, що викладачі, які працюють із студентами, мають відповідну кваліфікацію і високий фаховий рівень для здійснення своїх службових обов'язків". Однією із умов цього $є$ готовність, бажання і здатність професорсько-викладацького складу уміти отримувати та опрацьовувати сучасну наукову інформацію з усіх доступних джерел і використовувати ії у навчальному та науковому процесі. Для досягнення цього викладачі повинні довести свою здатність займатися наукою. Показниками $є$ бажання і цілеспрямованість випускників та викладачів університету щодо підготовки і захисту магістерських та кандидатських дисертацій. На відмінність від Європейського простору вищої освіти у нас ще $є$ і докторські дисертації, підготовка і захист яких свідчить уже про здатність науковця вносити суттєву новизну в наукові дослідження. Створення та саме функціонування навчальних закладів і нашого університету зокрема принципово залежить від того, чи зможуть вони мати такий науковий потенціал, який підніме університетську () Л. С. Бабінець, О. М. Сопель, К. О. Пашко науку на відповідний рівень і на цій основі забезпечить ефективний навчальний процес [1].

Основна частина. На момент заснування Тернопільського державного медичного інституту в ньому був лише медичний факультет (дата заснування 12 квітня 1957 р.), 3 травня 1979 р. був відкритий факультет післядипломної освіти, і вже за ініціативи ректора чл.- кор. НАМН проф. Л. Я. Ковальчука лише 30 червня 2000 р. був спочатку створений фармацевтичний, 1 вересня 2004 р. - стоматологічний факультет, а в грудні 2004 р. - факультет іноземних студентів. Одночасно на новостворених факультетах виникли і проблеми укомплектування їх науково-педагогічними кадрами. Однак ця ж проблема залишалася актуальною і для медичного факультету тому, що йшов поточний відтік професорсько-викладацького складу (вихід на пенсію, перехід до інших ВН3, еміграція тощо) та його постаріння. Вирішити іiі шляхом залучення науковців з інших ВНЗ можна було лише частково. Їх треба було забезпечити житлом, вони повинні були ознайомитися з традиціями колективу і влитися в нього та працювати з повною віддачею. Це не завжди в силу об'єктивних і суб'єктивних причин приносило бажані результати. Відповідно запрошувалися ті працівники, які були вкрай необхідні для започаткування роботи факультетів. Як показав досвід попередньо створених факультетів, підготовку викладацького складу слід робити із числа випус- 
кників свого університету. Притому акцент був зроблений на наявність на кожній кафедрі поєднання досвідчених викладачів 3 молодими, які потребували передачі досвіду від старших колег, що забезпечувало спадкоємність і наступність поколінь. Особливо почав відчуватися дефіцит науково-педагогічних працівників на теоретичних кафедрах. Керівництво університету почало вирішувати цю проблему декількома шляхами - проведенням відбору з числа студентів, які проявили схильність до наукової роботи за напрямками теоретичних кафедр ще під час навчання, прийомом випускників на роботу старшими лаборантами, які потім ставали здобувачами кандидатських дисертацій і після успішного захисту дисертацій зараховувалися на викладацькі посади, а також створенням відповідних умов для виконання дисертаційних робіт та матеріальним заохоченням.

Виконувачам дисертаційних робіт було дозволено користуватися при проведенні експериментальних досліджень віварієм університету, можливостями центральної науково-дослідної та міжкафедральної науково-клінічної лабораторій, а також друкувати безкоштовно статті у фахових журналах, які випускаються в університетському видавництві “Укрмедкнига".

Крім того, за ініціативою ректора Тернопільського державного медичного університету імені І. Я. Горбачевського чл.-кор. НАМН України, проф. Л. Я. Ковальчука від 17 червня 2011 року протокол № 14, ухвалою вченої ради Тернопільського державного медичного університету імені І. Я. Горбачевського, затвердженої наказом ректора від 8 червня 2011 року № 14, було введено преміювання тих, хто захистив дисертацію, у розмірі 5000 гривень та наукових керівників дисертацій - 10000 гривень, що суттєво вплинуло на хід і терміни виконання дисертаційних робіт.

Також приділяють увагу підготовці науково-педагогічних працівників і вчені ради навчально-наукових інститутів, на засіданнях яких двічі за рік розглядаються досягнуті результати та дотримання установлених термінів виконання дисертаційних робіт і створення дисертантам відповідних умов. Наприклад, за клопотанням вченої ради навчально-наукового інституту фармакології, гігієни та медичної біохімії ім. Скакуна ректором університету було дозволено виконувачам докторських дисертацій у дні, вільні від проведення занять зі студентами, готувати матеріали дисертаційних робіт поза межами своїх кафедр.

Але крім заходів зі сприяння та заохочення дисертантів, були розроблені і методи впливу на тих, хто не повністю усвідомлював важливість свого професійного росту. Наприклад, вчена рада університету рекомендувала ректору університету не продовжувати трудові відносини з викладачами, які протягом двох років роботи в університеті не запланували виконання дисертаційної роботи, а також переведення на 0,5 ставки старшого лаборанта тих здобувачів, які не вкладалися у затверджені терміни виконання дисертаційної роботи. Виключення робилися лише для тих викладачів, які за віком уже не встигали виконати дисертаційні роботи, але таких в університеті $€$ одиниці.

Для формування якісного кадрового складу університету важливим $€$ дотримання плану виконання професорсько-викладацьким складом дисертаційних робіт. Перевірка ходу виконання дисертацій повинна проводитися на систематичній і постійній основі. 3 цією метою в університеті було створено 5 комісій із числа найбільш досвідчених професорів (теоретичного, хірургічного, терапевтичного, стоматологічного та фармацевтичного профілів) 3 перевірки виконання дисертаційних робіт викладачами університету. Комісії регулярно вивчають стан виконання дисертаційних робіт кожним дисертантом і подають свої пропозиції керівництву університету.

За останні п’ять років відповідно до Концепції розвитку ТДМУ імені І. Я. Горбачевського (2006 р.) його колективу вдалося гармонійно поєднувати підготовку наукових кадрів і проведення наукових досліджень 3 оптимізацією навчальної роботи, що $є$ головною метою формування і подальшого розвитку системи вищої медичної освіти і нашого університету зокрема [2]. Про це свідчать такі показники: 32007 по 2011 рік було захищено 24 докторських дисертацій та 124 кандидатських дисертацій. В аспірантурі проходили підготовку 222 особи, з них в аспірантурі з відривом від виробництва навчалася 91 особа (в тому числі 1у цільовій аспірантурі Національного фармацевтичного університету та 2 -іноземних громадяни на контрактній формі навчання), без відриву від виробництва навчався 131 аспірант (в тому числі 3 - на умовах контракту). Ефективність аспірантури (як 3 відривом від виробництва, так і без відриву) становила $100 \%$. Слід відмітити, що у 2011 році 7 аспірантів достроково захистили кандидатські дисертації, 3 них 5 очних та 2 заочних.

Висновки. В університеті під керівництвом ректора чл. - кор. НАМН України, проф. Л. Я. Ковальчука створені всі належні умови для того, щоб професорсько-викладацький склад університету був укомплектований висококваліфікованими науково-педагогічними працівниками. Завдяки цьому колектив університету протягом наступних п'яти років на шля- 
ху до свого 60-річчя зможе гармонійно поєднувати подальший розвиток наукових досліджень 3 оптимі-

\section{Лiтература}

1. Стандарти і рекомендації щодо забезпечення якості в Європейському просторі вищої освіти (Свропейська асоціація із забезпечення якості вищої освіти). - К. : Вид-во “Ленвіт", 2006.-С. 7. зацією навчального процесу та удосконаленням навчальної та наукової матеріально-технічної бази.

2. Концепція розвитку Тернопільського державного медичного університету імені І. Я. Горбачевського (інтеграція у світовий медичний освітній простір). - Тернопіль : ТДМУ, 2006. -50 c. 